Jap. J. M. Sc. \& Biol., 9, 303-319, 1956

\title{
QUANTITATIVE STUDIES ON THE INTERACTIONS BETWEEN HERPES SIMPLEX VIRUS AND ECTODERMAL CELL OF CHORIOALLANTOIC MEMBRANE OF FERTILE HEN'S EGG BY MEANS OF THE COVER SLIP INFECTION SYSTEM
}

\section{ADSORPTION OF VIRUS ONTO CELLS ${ }^{1)}$}

\author{
KAMESABURo YOSHINO2) AND HIROKAZU TANIGUCHI ${ }^{3)}$ \\ Department of Virology \& Rickettsiology, National \\ Institute of Health, Tokyo4)
}

(Received: October 15th, 1956)

Elucidation of the mechanism of interactions between viruses and host cells has been advanced for the last decade most extensively in the studies on bacterial viruses. When similar investigations have been undertaken with animal viruses, there has been encountered the lack of an adequate host-virus system comparable to that of the bacterial virus from the viewpoint of exact quantitation. The basic conditions to be supplied by such host-virus system are (a) that host cells involved are uniformly susceptible to viral infection and react with the virus uniformly, (b) that for all virus particles there is an equal chance of access to cells, (c) that any desired number of virus particles can be brought in contact with known number of cells so as to adjust multiplicity of infection and finally (d) that the contact between virus and cells can be disrupted at any desired time by some appropriate means.

Various attempts have been made to meet these criteria. First, the allantoic cavity of the developing chick embryo, being lined exclusively by entodermal cells, has been widely utilized for host-virus quantitation of influenza (reference in Henle, 1953) and other viruses (Sigel et al., 1951; Gordon et al., 1952). Deembryonation technic more satisfactorily eliminated other tissues than entodermal cells from the system (Bernkopf, 1950; Finter et al., 1954). On the other hand, ectodermal cells of CAM (chorioallantoic membrane) of chick embryo have been utilized for similar studies on vaccinia (Briody and Stannard, 1951; Lépine et al., 1951; Oya, 1955) and herpes simplex viruses (Scott et al., 1953; Wildy, 1954; Modi and Tobin, 1954). Meanwhile, Scherer (1953) succeeded in propagating

1) This series of works were partially supported by the Fund for Scientifical Researches granted to Dr. M. Kitaoka, Chief of the Department of Virology \& Rickettsiology, National Institute of Health, Japan, from the Educational Ministry of Japan.

2)吉野亀三郎・3)谷口博一, 4)国立予防衛生研究所リケッチテ・ウイルス部 
herpes simplex and pseudorabies viruses in tissue culture with Earle's pure strain of cells, and Dulbecco and Vogt (1954a) demonstrated that tissue culture of monkey kidney and testis showed uniform susceptibility to poliomyelitis viruses. Weiss and Huang (1954) utilized in tissue culture chick embryo cells uniformly susceptible for feline and murine pneumonitis viruses.

To increase the chance of collision and regulate multiplicity between virus and cells, suspensions of single cells were obtained by the enzymic digestion of cells (Scherer, Syverton and Gey, 1953; Dulbecco and Vogt, 1954b). Other investigators have made use of Ehrlich ascites carcinoma and other tumor cells (Ackermann and Kurtz, 1952; Koprowska and Koprowski, 1953; Moore and Diamond, 1953), but the technical limitation for quantitation of this system lies in the short survival of the tumor cells in vitro.

In the meantime, the technical ease and high sensitivity with which pock counting titration of herpes simplex virus can be done led the present authors to the attempt to improve the regulation of multiplicity in the herpes virusectodermal cell system given by Scott et al. (1953), by utilizing the cover slip technic to be reported here. Although this method requires further refinement in the future new information on the mode of adsorption onto and multiplication within CAM cells of herpes virus has been derived from the use of this system which will be reported in this and subsequent papers (Yoshino and Taniguchi, $1956)$.

\section{MATERIALS AND Methods}

Virus: HF strain of herpes simplex virus was supplied through the courtesy of Dr. T. F. McNair Scott of the Children's Hospital of Philadelphia and the University of Pennsylvania, as infected CAM's of 318th egg passage and has been maintained in this laboratory by weekly passages on the CAM of 13-day old embryonated eggs. The 320th to the 392nd passages were used through the present series of experiments. The passage was done each time by inoculating $0.05 \mathrm{cc}$ of $10^{-3}$ dilution of $20 \%$ emulsion of previous stock CAM prepared as described below into each of several 13-day old eggs by the standard method (Scott, 1948). After 40 to 48 hours' incubation at $35^{\circ} \mathrm{C}$, the CAM's were harvested and put into test tubes containing $50 \%$ glycerine saline, which were then sealed with rubber-stopper and stored in the dry ice chest. The egg-adapted herpes virus stands long preservation under these conditions (Allen et al., 1952). During the two year period of study the titer has remained constantly high.

Buffered saline: This refers to $0.14 \mathrm{M} \mathrm{NaCl}$ solution in doubly distilled water buffered at $\mathrm{pH} 7.2$ with $0.01 \mathrm{M}$ phosphate buffer.

Yolk saline: Yolk of a fresh egg was added to the above buffered saline at $0.1 \%$ by volume, and this was stored at $0-4^{\circ} \mathrm{C}$ for not more than 2 weeks. Just prior to use, penicillin and streptomycin were added at concentrations of 500 units and $100 \mu \mathrm{g}$ per cc, respectively. Virus emulsions as well as dilutions therefrom were prepared with this diluent.

Seed preparation: Two CAM's of the same passage number, after storage for a period not exceeding 2 weeks, were thoroughly washed in 4 changes of about $10 \mathrm{cc}$ buffered saline, ground in a mortar for 1 minute with pyrex glass powder (mesh No. 
1, Shibata \& Co., pH 7.0), further ground for additional 30 seconds with a calculated amount of yolk saline to make a $20 \%$ emulsion and then spun at $2000 \mathrm{rpm}$ for 5 minutes. The supernate was designated $10^{-0}$ seed.

Pock counting titration: The titration method was essentially the same as was previously described by Scott (1948), except that for introduction of saline wedge between shell membrane and CAM a dull-pointed needle was inserted horizontally through the slit and that after inoculation no seal was used on the slit or on the air exit. Unless otherwise indicated, 4 eggs were used per dilution. Eggs in which the number of pocks deviated too much from the rest in the same dilution group were discarded. The number of pocks was then averaged for each dilution, which were in most cases roughly inversely proportional to the dilution factor. When the virus distribution over 2 or more consecutive dilutions was too much out of proportion or when appearance of non-specific pocks or non-responsive CAM's reduced the number of countable CAM's in key dilutions to less than 2 , such a titration result was regarded as "obscure". One standard deviation of the titration results5) preliminarily tested was $0.2 \log _{10}$ and therefore two titers showing a difference of more than $0.57 \log _{10}^{:}$are significantly different from each other with an error of less than $5 \%$.

Windowed egg: After dropping the CAM's of 13-day old eggs, the boundary of the false air sac was marked with pencil. Eggs showing comparatively large false air sacs were selected, and just inside of the air sac outline another elliptic line parallel to it was drawn on the shell. Along this inner line the shell, but not shell membrane, was cut with a carborundum disc. After sterilizing the shell with alcohol, the shell ellipse was removed together with shell membrane adhering to it. Eggs showing too much hemorrhage on the exposed CAM were not used, but when slight hemorrhage was present blood was evacuated from the false air sac cavity by turning the eggs over and they were used in the experiments.

Cover slip infection: The inoculum was smeared on the face of a glass cover slip, $18 \times 18 \mathrm{~mm}$, held by forceps and then the cover slip was placed on the exposed CAM of a windowed egg with the smeared face down. In order to avoid damage to the CAM, corners of cover slip had been rounded but only to such an extent that this did not affect its size materially. After inoculation the window was covered with another cover slip of larger size, $24 \times 32 \mathrm{~mm}$, and incubation was made at $35^{\circ} \mathrm{C}$. Fixation of this large cover slip to the shell with paraffin was not necessary, since eggs without such sealing showed no appreciable difference from non-windowed eggs in embryonic development or pock formation during the subsequent 2 days.

Recovery of residual, unadsorbed virus: On completion of the planned period of incubation, yolk saline was introduced into the false air sac cavity of the egg in an amount which made the total volume of fiuid in it up to $2.0 \mathrm{cc}$. Except for the first few experiments recorded in Table 1, 0.02 cc inoculum was used for infection and therefore $1.98 \mathrm{cc}$ of yolk saline was needed in this step. The small cover slip placed on CAM at infection was removed and rinsed in the added yolk saline thoroughly. After removing the rinsed cover slip from the egg, additional stirring of the fluid over the CAM was carried out with forceps. This procedure was called washing-in-shell. The washing fluid, thus well mixed with the previous inoculum, was pipetted off. Then

5) Calculation was made from 2 neighboring dilutions which gave countable pocks by

$$
\mathrm{N}=(\mathrm{a}+\mathrm{b}) \times \frac{1}{1.1} \times \frac{1}{0.05} \times 10^{\mathrm{p}}
$$

where $a$ and $b$ are average pock numbers for $10^{\mathrm{P}}$ and $10^{\mathrm{P}+1}$ dilutions, respectively, and $\mathrm{N}$ is number of infectious units per ce of undiluted material. 
each egg was examined for presence of CAM damage by turning it in various directions. Washings obtained from eggs showing damage of the CAM as evidenced by leakage of allantoic fluid were discarded. All tests were performed in duplicate and the washings thus obtained from parallel eggs were pooled and titrated.

Glucose solution: Glucose (Merck, extra pure) was dissolved in doubly distilled water at $0.15 \mathrm{M}$ concentration and heated at $100^{\circ} \mathrm{C}$ for 15 minutes. A freshly prepared solution was used each time. The $\mathrm{pH}$ was 6.1 but no adjustment was done, because degradation of HF virus in this solution at room temperature was found to be little even after one hour.

Antiserum: Rabbits were immunized by 5 intravenous injections of freshly prepared emulsions of infected CAM. The antisera obtained were heated at $56^{\circ} \mathrm{C}$ for 30 minutes and stored in the dry ice chest. For the sake of uniformity only one antiserum which showed the titer of 1:256 or a little higher was used throughout the present series of experiments. This was checked by neutralization tests repeatedly carried out during the two-year period after the standard method given by Scott et al. (1949). Dilution of antiserum was made with buffered saline.

Further details and alterations of technics are described in the text.

\section{Preliminary ANalyses of Methods}

Size of inoculum: At first, the optimal size of inoculum was determined, employing 3 different amounts, $0.01,0.05$ and $0.1 \mathrm{cc}$, in 5 tests recorded in Table 1, which indicated no marked difference among these 3 sizes in the rate of recovery of residual virus. The $0.01 \mathrm{cc}$ size was so small that it exaggerated the error range in measuring, and the two larger sizes were too much to be evenly smeared on cover slip. For these reasons, it was decided to use 0.02 cc inoculum exclusively in all the experiments which will be described hereafter.

Thermal degradation of $H F$ virus in yolk saine: It was previously pointed out by Scott et al. (1953) that this same strain of HF virus underwent slow

Table 1. Virus recovery after different amounts of inoculum

\begin{tabular}{|c|c|c|c|c|c|c|c|}
\hline \multirow{2}{*}{$\begin{array}{l}\text { Exp. } \\
\text { No. }\end{array}$} & \multirow{2}{*}{$\begin{array}{c}\text { Amount of } \\
\text { inoculum }\end{array}$} & \multirow{2}{*}{$\begin{array}{l}\text { Virus in inoculum } \\
\text { (inf. u.)* }\end{array}$} & \multicolumn{5}{|c|}{$\%$ Recovered virus after } \\
\hline & & & $30 \mathrm{~min}$. & $1 \mathrm{hr}$. & $2 \mathrm{hrs}$. & $3 \mathrm{hrs}$. & $6 \mathrm{hrs}$. \\
\hline 1 & $0.01 \mathrm{cc}$ & $1.1 \times 10^{6}$ & 14 & & 16 & & \\
\hline 2 & $"$ & $2.2 \times 10^{6}$ & & 37 & & & 15 \\
\hline 3 & 0.05 & $1.1 \times 10^{7}$ & & 76 & & & 37 \\
\hline 4 & " & $7.8 \times 10^{6}$ & & 54 & & 32 & 9.1 \\
\hline 5 & 0.1 & $1.6 \times 10^{7}$ & & 61 & & 34 & \\
\hline
\end{tabular}

* inf. u.: infectious units as determined by pock counting titration.

thermal degradation in vitro when suspended in $0.5 \%$ gelatin saline with or without normal CAM extract. In our present study, similar tests were done with yolk saline. Four experiments with undiluted seeds and 2 with 10-3 diluted seeds are illustrated in Fig. 1, in which degradation is expressed as the percentage of 


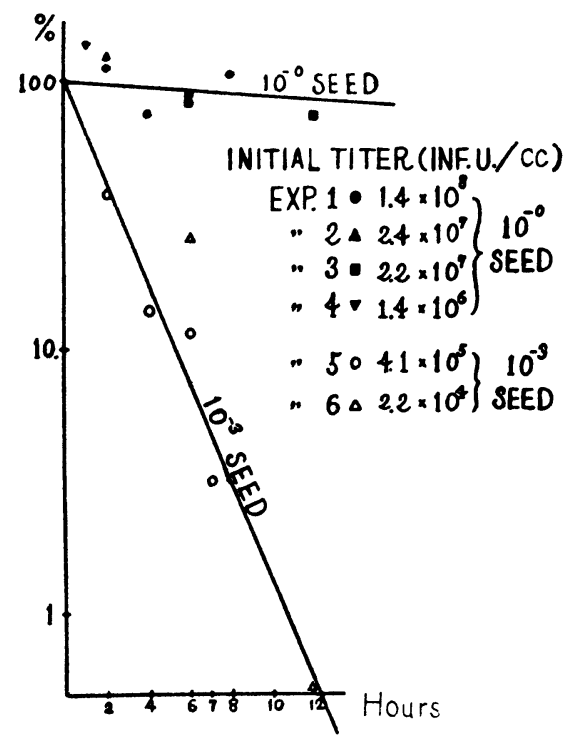

Fig. 1. Thermal degradation of HF virus in yolk saline in vitro. $10^{-0}$ seed means $20 \%$ emulsion of infected CAM prepared with yolk saline. Temperature was $35^{\circ} \mathrm{C}$.

initial virus surviving after varying periods of incubation at $35^{\circ} \mathrm{C}$. As is clearly seen in the figure, undiluted seeds showed little decrease of titer even at the end of 12 hours, while virus in $10^{-3}$ dilution was subject to comparatively rapid inactivation. A similar stability of herpes virus in undiluted mouse brain emulsion was noted by Zinnser and Tang (1929).

It was further noted that thermal degradation of the virus suspension sandwitched between glass or thinly smeared on glass roughly parallelled that in test tube, provided that evaporation was prevented.

\section{RESULTS}

The Proportion of Inoculated Virus Recoverable as Unadsorbed Virus at Various Periods after Inoculation

In order to estimate the amount of residual virus after various incubation periods, 28 experiments were performed, of which 6 showed obscure seed titration results and therefore were omitted. The results of the 22 successful experiments are presented in Table 2, where the data are arranged in order of the titer of seed virus.

A fairly constant proportion of residual virus was recovered at each adsorption period, except at 15 minutes where fluctuations in the recovery rate was somewhat wider than at the other incubation periods tested. The experiments were grouped according to the seed dilutions used for inoculation and the geometric mean of the recovery rates at each adsorption period was calculated 
Table 2. Proportion of inoculated virus recoverable as unadsorbed virus at varying periods after inoculation

(1) (Experiments with $10^{-0}$ seed)

\begin{tabular}{ccccccccc}
$\begin{array}{c}\text { Virus in inoculum } \\
\text { (inf. u.) }\end{array}$ & \multicolumn{7}{c}{$\%$ Recovered virus after } \\
\cline { 2 - 8 } & 1 min. & 5 min. & 15 min. & 30 min. & 1 hr. & 2 hrs. & 4 hrs. & 6 hrs. \\
\hline $1.1 \times 10^{7}$ & - & - & - & - & - & - & - & 5.6 \\
$5.8 \times 10^{6}$ & - & - & - & 24 & - & - & - & - \\
$4.6 \times 10^{6}$ & - & - & - & - & - & 16 & - & - \\
$4.6 \times 10^{6}$ & - & 74 & 20 & 26 & 22 & - & - & - \\
$3.9 \times 10^{6}$ & - & - & - & 31 & 24 & - & - & - \\
$1.8 \times 10^{6}$ & - & - & 78 & - & - & - & - & - \\
$1.6 \times 10^{6}$ & - & - & - & 9.4 & - & - & - & - \\
$1.5 \times 10^{6}$ & - & - & - & - & 7.5 & - & - & - \\
$1.5 \times 10^{6 *}$ & - & - & - & $65 * *$ & $33^{* *}$ & - & - & - \\
& & & & 40 & 32 & & & \\
$1.3 \times 10^{6}$ & - & - & - & 54 & - & - & - & - \\
$1.3 \times 10^{6}$ & - & - & - & - & 12 & - & - & - \\
$1.3 \times 10^{6}$ & 110 & 81 & 58 & - & 15 & 9.2 & - & - \\
$1.2 \times 10^{6}$ & - & - & - & 28 & - & - & - & - \\
$9.8 \times 10^{5}$ & - & - & 91 & - & - & - & - & - \\
$6.5 \times 10^{5}$ & - & - & - & - & -- & - & - & 17 \\
$4.8 \times 10^{5}$ & - & - & - & - & 13 & 18 & - & - \\
\hline Geometric mean & 110 & 77 & 54 & 31 & 17 & 15 & 9.7 \\
\hline
\end{tabular}

(2) (Experiments with $10^{-1}$ seed)

\begin{tabular}{ccccccccc}
\hline $4.6 \times 10^{5}$ & - & - & - & - & 48 & 37 & 7.2 & 3.3 \\
$8.8 \times 10^{4}$ & - & - & - & 6.4 & 11 & 16 & - & - \\
\hline Geometric mean & & & & 6.4 & 22 & 24 & 7.2 & 3.3 \\
\hline
\end{tabular}

(3) (Experiments with $10^{-2}$ seed)

\begin{tabular}{ccccccccc}
\hline $\begin{array}{c}4.6 \times 10^{4} \\
1.5 \times 10^{4}\end{array}$ & - & 120 & 30 & 19 & 17 & 7.8 & 15 & 0.52 \\
$1.2 \times 10^{4}$ & - & - & - & 24 & - & - & - & - \\
$6.5 \times 10^{2}$ & - & - & - & - & - & - & & $<6.2^{* * *}$ \\
\hline Geometric mean & & 120 & 30 & 21 & 17 & 21 & 15 & \\
\hline \hline $\begin{array}{c}\text { Geometric mean } \\
\text { from the total }\end{array}$ & 110 & 90 & 48 & 25 & 18 & 18 & 10 & \\
\hline
\end{tabular}

* Two serial dilutions were made from the same seed and titrated in duplicate; the titers were $1.4 \times 10^{6}$ and $1.6 \times 10^{6}$.

** Three serial dilutions were made from the same pool of washings and the

3 titers obtained are recorded here.

*** No pock in $4 \times 0.05$ ce of undiluted material.

- Not tested. 
separately for each group.

In the group of $10^{-0}$ seed, the amount of residual virus was greater within 5 minutes than at 30 minutes or later where a stationary status was sustained up to the longest observation time, 6 hours, indicating that adsorption was not complete within 5 minutes but practically came to an end by 30 minutes after inoculation. This trend was observed also in the experiments with $10^{-1}$ and $10^{-2}$ seeds, and the virus recovery rate during the stationary period was roughly at the same level, regardless of seed dilution used. One exception was the rate of residual virus at 6 th hour in the group of $10^{-2}$ seeds. Whether this is due to faster degradation of virus in diluted seed as revealed in Fig. 1 or to other reasons is not clear.

The rates recorded in Table 2 for the periods between 30 minutes and 2 hours inclusive were statistically analysed. This gave a geometric mean of $20 \%$ with a reliable range $(\mathrm{P}=0.05)$ between $16 \%$ and $26 \%$.

\section{Localization of Unadsorbed Virus}

With the method presented here, in which washing-in-shell of infected CAM by vigorous stirring was done, one might suspect that the virus recovered as "residual, unadsorbed virus" contained virus which had been detached from CAM after being once adsorbed. This possibility was tested as follows.

Windowed eggs were infected by the cover slip method with $10^{-0}$ seed and after incubation for stated times a pair of eggs was selected at random and their cover slips were removed and rinsed thoroughly in $4.0 \mathrm{cc}$ of yolk saline. Then sterile gauze was placed on the infected area of CAM of these eggs to absorb the remaining inoculum and squeezed repeatedly in the same yolk saline which was used for rinsing of the cover slips. Then $2.0 \mathrm{cc}$ of new yolk saline was added to each windowed egg and washing-in-shell was done as usual to recover virus from the surface of CAM.

The results with 3 different adsorption periods, 1/2, 1 and 6 hours, gave almost the same distribution of "unadsorbed virus" among respective materials titrated. The amount of virus recovered from the cover slip and the remaining inoculum was of the same order as that of the "unadsorbed virus" previously calculated while the amount of virus subsequently washed off the CAM surface was much less than that, averaging $2.7 \%$ of the inoculated virus, or $8.9 \%$ of the supernatant virus, as can be seen in Table 3 .

Then arose the question of whether or not this "unadsorbed virus" had come off the glass cover slip, and two experiments were performed using the same method as in the preceding test except that the cover slip was drained of excess fluid by touching the edge to filter paper, then rinsed and the rinse titrated separately from that of the fluid squeezed from the gauze sponge. It was clearly demonstrated thereby that most of the "unadsorbed virus" was in the inoculum and did not come from the cover slip. The results are shown in Table 4. 
Table 3. Localization of 'unadsorbed virus'. I. Separate titration of supernatant inoculum and subsequent washing

\begin{tabular}{|c|c|c|c|c|c|c|}
\hline \multirow[b]{2}{*}{ Time } & \multirow{2}{*}{$\begin{array}{l}\text { Virus in } \\
\text { inoculum } \\
\text { (inf. u.) }\end{array}$} & \multicolumn{4}{|c|}{ Virus recovered from } & \multirow[b]{2}{*}{ (a) : (b) } \\
\hline & & $\begin{array}{l}\text { Inoculun } \\
\text { inf. u. (a) }\end{array}$ & $\%$ & $\begin{array}{l}\text { CAM sur } \\
\text { inf. u. (b) }\end{array}$ & $\begin{array}{l}\text { ace } \\
\%\end{array}$ & \\
\hline $30 \mathrm{~min}$. & $3.9 \times 10^{6}$ & $2.4 \times 10^{6}$ & 62 & $8.4 \times 10^{4}$ & 2.1 & $1: 0.034$ \\
\hline $1 \mathrm{hr}$. & 川 & $1.1 \times 10^{6}$ & 29 & $3.2 \times 10^{5}$ & 8.1 & $1: 0.28$ \\
\hline $6 \mathrm{hrs.}$ & ” & $6.0 \times 10^{5}$ & 15 & $4.8 \times 10^{4}$ & 1.2 & $1: 0.078$ \\
\hline \multicolumn{2}{|c|}{ Geometric mean } & & 30 & & 2.7 & $1: 0.089$ \\
\hline
\end{tabular}

Table 4. Localization of 'unadsorbed virus'. II. Separate titration of supernatant inoculum and cover slip rinsing

\begin{tabular}{ccccccc}
\hline \multirow{2}{*}{ Time } & $\begin{array}{c}\text { Virus in } \\
\text { inoculum } \\
\text { (inf. u.) }\end{array}$ & \multicolumn{4}{c}{ Virus recovered from } & Inoculum \\
\cline { 3 - 5 } & & inf. u. (a) & Cover slip rinsing & (a) : (b) \\
inf. u. (b) & $\%$ & \\
\hline 2 hrs. & $*$ & $1.6 \times 10^{6}$ & & $6.4 \times 10^{4}$ & & $1: 0.040$ \\
$6 \%$ & $1.3 \times 10^{6}$ & $2.5 \times 10^{5}$ & 19 & $3.5 \times 10^{4}$ & 2.6 & $1: 0.14$ \\
\hline
\end{tabular}

* Seed titration result was obscure in this case.

\section{Pock Formation on Infected CAM}

The experiments thus far recorded demonstrated that at least $74 \%$ of the inoculated virus disappeared from inoculum after 15 to 30 minutes' incubation and that a stationary status was then established. However, when the CAM thus infected was washed in buffered saline and examined for presence of virus, the titer was far less than would be expected by the subtraction of the unadsorbed from the total inoculated virus. A similar phenomenon was found by Henle (1949) and Hoyle (1950) in the influenza virus-chick embryo system and ascribed to the existence of a non-infectious phase of virus in the initial period of growth cycle.

However, it might also be possible that the decrease in titer of the inoculum is caused by adsorption of part of virus to the glass cover slip as well as by spread of virus to other tissues of the embryo. The former seems to have been disproved by the experiment just described. Examination of the latter hypothesis was attempted by demonstrating that virus grew only in the area of the CAM covered with the cover slip. This was done as follows.

Windowed eggs were infected by the cover slip method with seeds appropriately diluted so that countable pocks would appear on CAM. After stated times of incubation the cover slip was removed and sterile gauze piece was placed on the CAM to absorb the inoculum. Then $0.1 \mathrm{cc}$ of antiserum was added. In the first few experiments, undiluted serum was used, but later $10^{-1}$ diluted serum was preferred because this caused the appearance of fewer non-specific 
pocks. The number of eggs used per dilution varied as appears in Table 5.

A disadvantage inherent to these technics was that the cover slip resulted in appearance of non-specific lesions in a greater number of eggs than encountered in the usual titration. Nevertheless in a sufficient number of the eggs, approximately one third, typical pocks appeared in the area of a square on the infected CAM, which corresponded in size and shape to the cover slip. Membranes randomly selected from these experiments are photographically shown in Fig. 2. In comparison with them, Fig. 3 demonstrates spread of virus over the whole exposed area of CAM in usual titration.

A survey of Table 5 gives the impression that the greater part of the virus inoculated under the cover slip is attached to cells within 15 to 30 minutes, or at latest one hour, following inoculation. This is in support of the previous estimation that virus adsorption is practically over within thirty minutes after contact with CAM cells.

When 3 times washing-in-shell with gauze sponging in between was done instead of addition of antiserum, a similar trend was observed.

\section{Reexamination of Adsorption Rate by Titrating the CAM after 18 Hours' Incubation}

From the data thus far reported, the general trend of the adsorption curve has been depicted. This was supported by the results of the following experiment.

Table 5. Pock formation on CAM of eggs which were infected and added with antiserum at various times after inoculation

\begin{tabular}{rccccccrrr}
\hline Exp. & $\begin{array}{c}\text { No. of } \\
\text { eggs } \\
\text { No. }\end{array}$ & $\begin{array}{c}\text { Dilution } \\
\text { of } \\
\text { group }\end{array}$ & $\begin{array}{c}\text { Dilution } \\
\text { of } \\
\text { antiserum }\end{array}$ & $\begin{array}{c}\text { Virus in } \\
\text { inoculum } \\
\text { seed }\end{array}$ & \multicolumn{4}{c}{$\begin{array}{c}\text { Interval between infection and } \\
\text { antiserum }\end{array}$} \\
\hline 1 & 2 & $10^{-0}$ & $10^{-3}$ & 1200 & $6+$ & 11 & $*$ & cnf. & cnf. \\
2 & 8 & $10^{-1}$ & $10^{-4}$ & 127 & & & & 118 & 130 \\
3 & 2 & $10^{-0}$ & $10^{-4}$ & 120 & $*$ & 7 & 6 & 20 & 94 \\
4 & 4 & $10^{-0}$ & $10^{-4}$ & 69 & & $*$ & $*$ & $*$ & 85 \\
5 & 4 & $10^{-0}$ & $10^{-4}$ & 43 & & & & 50 & 41 \\
6 & 2 & $10^{-0}$ & $10^{-5}$ & 14 & 2 & $*$ & 2 & 17 & 5 \\
7 & 4 & $10^{-1}$ & $10^{-5}$ & 13 & & & & 7 & 14 \\
8 & 2 & $10^{-0}$ & $10^{-5}$ & 12 & $*$ & $*$ & 13 & 7 & 14 \\
9 & 20 & $10^{-1}$ & $10^{-4.5}$ & 10 & & & 8 & 18 & \\
10 & 4 & $10^{-0}$ & $10^{-5}$ & 7 & & 5 & $*$ & $*$ & 6 \\
\hline
\end{tabular}

$\dagger$ : Figures express average number of pocks.

* : Obscure due to appearance of non-specific lesions and/or non-responsive CAM's.

enf. : Confluent plaques.

\# : Calculated from seed titration.

The data are arranged in the sequence of seed virus titer. 
Twelve windowed eggs were infected by the cover slip method with the same seed and incubated as usual. After 15 minutes the cover slips were removed from $1 / 2$ of these, and the eggs returned to incubator. From the other half the cover slips were also removed but in addition inocula were sponged off with sterile gauze pieces until no more liquid was absorbable, after which they were returned to incubator. At 18th hour after infection, each group was divided into 3 subgroups each of 2 eggs. From each pair the CAM's were cut off, washed in 4 changes of $10 \mathrm{cc}$ buffered saline and emulsified with $4.0 \mathrm{cc}$ yolk saline. Titration was carried out upon each of the 6 subgroups. Geometric means of the titers obtained in each of the 3 subgroups were calculated.

The results are given in Table 6, where it can be seen that the geometric means were close to each other which would indicate that adsorption of virus proceeds rapidly and is almost complete by 15 minutes after infection. This conclusion confirms the results given by Scott et al. (1953), who added antiserum to eggs infected with herpes virus after varying times following infection and titrated the CAM's later.

\section{Attempts to Elute the Adsorbed Virus with Isotonic Glucose Solution}

Attempts have been made to see if lowering of ionic strength in the environment would elute the virus sticking to cell wall, especially when adsorption had proceeded at low temperature. However, no success was obtained in the following experiments.

Virus was inoculated by the cover slip method and after various periods of incubation under different conditions of temperature the unadsorbed virus was

Table 6. Rate of virus adsorption demonstrated by titrating the eggs at 18th hour with or without previous sponging off of inoculum at 15 minutes

\begin{tabular}{|c|c|c|c|c|}
\hline $\begin{array}{l}\text { Virus in } \\
\text { inoculum } \\
\text { (inf. u.) }\end{array}$ & $\begin{array}{l}\text { Sponging off } \\
\text { at } 15 \text { th min. }\end{array}$ & Subgroup & $\begin{array}{l}\text { Virus/CAM } \\
\text { (inf. u.) } \\
\text { at 18th hr. }\end{array}$ & Geometric mean \\
\hline \multirow{6}{*}{$5.5 \times 10^{6}$} & \multirow{3}{*}{ Done } & 1 & $6.2 \times 10^{7}$ & \multirow{3}{*}{$4.9 \times 10^{7}$} \\
\hline & & 2 & $3.0 \times 10^{7}$ & \\
\hline & & 3 & $\left.6.4 \times 10^{7}\right)$ & \\
\hline & \multirow{3}{*}{ Not Done } & 1 & $5.1 \times 10^{7}$ & \multirow{3}{*}{$5.1 \times 10^{7}$} \\
\hline & & 2 & $6.7 \times 10^{7}$ & \\
\hline & & 3 & $3.9 \times 10^{7}$ & \\
\hline
\end{tabular}

recovered as usual. Each time, CAM's from a pair of eggs were cut off, washed in 4 changes of $10 \mathrm{cc}$ buffered saline, then placed in a test tube which contained $4.0 \mathrm{cc}$ of glucose solution and after sealing with a rubber-stopper the test tube was vigorously shaken by hand. Quickly the washed CAM's were transferred to the next tube of glucose solution. This washing was repeated 11 times and 
Table 7. Failure in the attempts to reverse the viral adsorption by means of washing with glucose solution

\begin{tabular}{|c|c|c|c|c|c|c|}
\hline \multicolumn{2}{|c|}{$\begin{array}{l}\text { Conditions of } \\
\text { adsorption }\end{array}$} & \multirow{2}{*}{$\begin{array}{l}\text { Virus in } \\
\text { inoculum } \\
\text { (inf. u.) }\end{array}$} & \multicolumn{4}{|c|}{$\%$ Virus recovered from } \\
\hline $\begin{array}{l}\text { Tempera- } \\
\text { ture }\end{array}$ & Time & & $\begin{array}{c}\text { First YS } \\
\text { washing } \\
\text { (unadsorbed) }\end{array}$ & $\begin{array}{l}\text { 1st-10th } \\
\text { glucose } \\
\text { washings }\end{array}$ & $\begin{array}{l}\text { 11th } \\
\text { glucose } \\
\text { washing }\end{array}$ & $\underset{\text { emulsion }}{\text { CAM }}$ \\
\hline $35^{\circ} \mathrm{C}$ & $15 \mathrm{~min}$. & $1.3 \times 10^{6} \#$ & 78\# & $2.4 \#$ & $0.01 \#$ & $0.53 \#$ \\
\hline , & $30 ״$ & $1.2 \times 10^{6}$ & 28 & 3.2 & 0.04 & 0.18 \\
\hline $20^{\circ} \mathrm{C}$ & $1 \mathrm{hr}$. & $1.2 \times 10^{6}$ & 28 & 1.9 & 0.03 & 0.40 \\
\hline $0^{\circ} \mathrm{C}$ & 1 & $4.8 \times 10^{6}$ & 76 & 1.5 & 0.04 & 0.08 \\
\hline 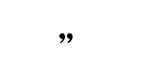 & 2 & $4.8 \times 10^{6}$ & 79 & 4.7 & 0.04 & * \\
\hline ” & 9 & $1.9 \times 10^{6}$ & 38 & 1.6 & 0.02 & 0.20 \\
\hline
\end{tabular}

finally the CAM's were emulsified with glucose solution. The 1st to 10th glucose washings were pooled and titrated separately from the 11th washing.

These experiments were done in an attempt to elute virus after once adsorbed to cells. However, quite on the contrary, in none of these was more than a very small fraction of the inoculated virus recovered, indicating that in this system the virus could not be eluted with non-ionic solutions.

\section{Discussion}

The main purpose of the present work was to establish a simple host-virus system suited for quantitative studies on host-virus interactions. Therefore, the applicability and limitation of the cover slip infection system for such quantitation will be discussed briefly.

It appears evident that at least during the initial contact between virus and cells no other cells are involved in the host-virus interactions than ectodermal cells which are covered by inoculum at the time of inoculation. It can be seen from the photograph (Fig. 2) that virus taken up by these cells does not disperse rapidly throughout the egg, since pock formation is confined to an area corresponding in size and shape to the cover slip used.

However, it is inevitable even in the present system that some virus particles are located nearer CAM surface than others. The furthest distance is theoretically $0.06 \mathrm{~mm}$ when $0.02 \mathrm{cc}$ inoculum is used, that is 300 to 400 times the diameter of virus particle. This calculation is based on the assumption that CAM surface is fairly plain, but if long protrusions from normal cell surface are present, as indicated by Hoyle (1950), Murphy and Bang (1952) and Wyckoff (1953), collision efficiency between virus and cells may be higher. The preliminary tests (Table 1) showed that adsorption occurred rapidly even when the inoculum 
size was 0.05 to $0.1 \mathrm{cc}$, so that distance of virus particle from the surface of the cell did not appear to play a part.

Quantitation of dose of virus per cell can also be approached by this method in that the pock-forming unit may be equated with the infectious unit in a fixed proportion. That this proportion is close to one will be demonstrated in the subsequent paper. Furthermore, it has been possible to remove virus from its contact with the host cell by mechanical means (gauze sponging) and addition of antiserum. It would seem then that the technics suggested met the four criteria established in the introduction as requirements for the study of hostvirus relationships on a quantitative basis provided that these studies were confined to a few hours after inoculation of the virus onto the host.

On the above premise these studies revealed the following facts concerning the adsorption of herpes virus onto the ectodermal cells of the CAM.

1. Rate of adsorption: On the basis of three experimental approaches, titration of residual virus, pock formation on the membrane after original inoculum had been neutralized by antiserum at various periods after inoculation, and titration of virus in the CAM after 18 hours' incubation when the original inoculum had been removed at $\mathbf{1 5}$ minutes, it appears that a stationary status is established by 30 minutes after inoculation leaving $20 \%$ of the inoculated virus as residual, unadsorbed virus. Scott et al. (1953) pointed out that the proportion of residual virus as recovered by their method was in the order of one percent or its fraction and their results would seem contradictory to our present data. However, this difference might be ascribed to the different methods used for infection as well as for virus recovery. Wildy (1954) and Modi and Tobin (1954) gave the proportions of residual virus which were close to our present data.

An interesting information revealed in our present studies is that the existence of a stationary period following the initial adsorption stage is unequivocal. A similar stationary period may be commonly found in many host-virus systems. Henle (1949) first disclosed this in the influenza-chick embryo system and called it "constant period", but later Horsfall (1954), using the same host-virus system, denied the presence of such a stationary period and insisted on the logarithmic decrease of residual virus. Recently, however, Levine and Sagik (1956) pointed out that NDV adsorbed rapidly to tissue-cultured chick embryo cells leaving some portion unadsorbed for a long time. By and large, presence of such a stationary period in a host-virus system, if any at all, might be difficult to determine, if the first release of newly produced virus occurs in a short period following infection. In our present case, however, the initial attachment of virus is sufficiently rapid (Tables 2, 5 and 6) and the first cycle latent period is sufficiently long (Yoshino and Taniguchi, 1956). If the residual virus had decreased logarithmically, there would have been little detectable virus at the 6th hour following infection. Nevertheless, when $10^{-0}$ seed was used, more or 
less $20 \%$ of inoculated virus was consistently recovered at the 6 th hour (Tables $1,2,3$ and 4$)$.

2. Failure in the attempt to elute virus: It has been our knowledge that ions, or electrolytes, play an important role in many biological combination systems. In the field of virology too, Delbrueck (1940b) found reversibility of bacteriophage adsorption to sintered glass filter by washing with distilled water. Such reversibility of T2 bacteriophage was also testified by Puck, Garen and Coline (1951) in its binding with the host bacterial cells. With animal viruses too, a number of informations are available which point to the necessity of ions for adsorption of virus to tissues or erythrocytes (Burnet and Edney, 1952; Lowell and Buckingham, 1948; Flick et al., 1949; Davenport and Horsfall, 1948; Levine and Sagik, 1956). Ginsberg and Horsfall (1951) could release PVM hemagglutinin abundantly from infected mouse lungs with distilled water. Likewise, Morris (1953) used distilled water for better release of GDVII virus from infected mouse brains. Lahelle and Ward (1951) purified this virus by hemagglutination followed by elution with isotonic glucose solution. Therefore, in the present studies, lowering of ionic strength by repeated washing with isotonic glucose solution was expected to elute the virus after once adsorbed to cells. However, contrary to this expectation, only a few percent of inoculated virus was recovered.

This fact may not exclude the postulate for presence of reversible stage in the attachment of virus comparable to that of T2 bacteriophage (Garen and Puck, 1951), because in the present host-virus system no means has been found as yet which could prevent the viral penetration into the cells so that all the adsorbed virus particles would be reversed at one time. Levine and Sagik (1956) also reported that NDV attachment to cells could not be reversed by the $\mathrm{pH}$ change which would have reversed its attachment to red blood cells.

In our experiments (Table 7), it is noteworthy that the last glucose washing contained only $0.04 \%$ or less of the inoculated virus while the final CAM emulsion, also prepared with glucose solution, showed about 10 times as much virus. This fact may mean that some portion of adsorbed virus can not readily elute by mere washing but, on grinding the CAM in glucose solution, can be liberated. The reason for this will be discussed in the next paper (Yoshino and Taniguchi, 1956).

3. Significance of unadsorbed virus: The significance of the presence of residual, unadsorbed virus at constant percentage during the observed period was of special interest and several postulations were made to account for it. However, experiments thus far carried out could not reach a decisive answer to the question of whether it means presence of two kinds of virus particles possessing different speed of adsorption, as suggested by Schlesinger (1932) and Delbrueck (1940a) in bacteriophage adsorption and by Levine and Sagik (1956) in NDV adsorption to chick embryo cells, or production of inhibitor for viral adsorption from infected cells. The only data available at hand indicate that 
this is not due to induction of cell wall change after infection as is the case in ovum-sperm mechanism nor to influence of $35^{\circ} \mathrm{C}$ incubation on the adsorbing power of virus particles. Further studies are necessary to clear out this point.

\section{SUMMARY}

Employing the false air sac technique with a window opening and the inoculum on a glass cover slip, herpes simplex virus was applied to a known area of ectodermal cells and the adsorption of virus under these circumstances was studied quantitatively. The following facts were demonstrated. The adsorption of the virus onto the cells proceeded rapidly and practically came to an end by 30 minutes following inoculation, leaving approximately $20 \%$ of inoculated virus as residual virus which remained constant for the next few hours. Virus once adsorbed could not be removed from the host cells by any means tested, but reduction of ion concentration seemed to elute a very small portion of adsorbed virus. The signifacance of the presence of unadsorbed virus during the stationary period remains to be clarified by further studies.

The authors are greatly indebted to Dr. T. F. McNair Scott, Children's Hospital of Philadelphia, University of Pennsylvania, for frequent encouragement and valuable advices as well as for his kind help in the preparation of manuscripts of the present series of papers, and to no less extent to Dr. M. Kitaoka, Chief of the Department of Virology and Rickettsiology, National Institute of Health, for kind facilitation for the present works.

\section{REFERENCES}

Ackermann, W. W. and Kurtz, H. (1952): A new host-virus system. Proc. Soc. Exper. Biol. \& Med., 81, 421-423.

Allen, E. G., Kaneda, B., Girardi, A. J., Scott, T. F. McN. and Sigel, M. M. (1952) : Preservation of viruses of the psittacosis-lymphogranuloma venerum group and herpes simplex under various conditions of storage. J. Bact., 63, 369-376.

Bernkopf, H. (1950): Study of infectivity and hemagglutination of influenza virus in deembryonated eggs. J. Immunol., 65, 571-583.

Briody, B. A. and Stannard, C. (1951): Studies on vaccinia virus I. The development of hemagglutination and infective particles in the chorioallantois of the chick embryo. J. Immunol., 67, 403-411.

Burnet, F. M. and Edney, M. (1952) : Influence of ions on the interaction of influenza virus and cellular receptors or soluble inhibitors of hemagglutination. Australian J. Exper. Biol. \& M. Sc., 30, 105-118.

Davenport, E. M. and Horsfall, F. L., Jr. (1948): The associative reactions of pneumonia virus of mice (PVM) and influenza virus: the effect of $\mathrm{pH}$ and electrolytes upon virus-host cell combination. J. Exper. Med., 88, 621-644.

Delbrueck, M. (1940a): Adsorption of bacteriophage under various physiological conditions of the host. J. Gen. Physiol., 23, 631-642.

Delbrueck, M. (1940b) : The growth of bacteriophage and lysis of the host. J. Gen. Physiol., 23, 643-660 
Dulbecco, R. and Vogt, M. (1954a) : Plaque formation and isolation of pure line with poliomyelitis viruses. J. Exper. Med., 99, 167-182.

Dulbecco, R. and Vogt, M. (1954b) : One-step growth curve of western equine encephalomyelitis virus on chicken embryo cells grown in vitro and analyses of virus yields from single cells. J. Exper. Med., 99, 183-199.

Finter, N. B., Liu, O. C., Lieberman, M and Henle, W. (1954): Studies on host-virus interactions in the chick embryo-influenza virus system VIII. An experimental analysis of various deembryonation technics. J. Exper. Med. 100, 33-52.

Flick, J. A., Sanford, B. and Mudd, S. (1949): The effect of salt concentration on the interaction of influenza $A$ virus and erythrocytes. J. Immunol., 61, 65-78.

Garen, A. and Puck, T. T. (1951): The mechanism of virus attachment to host cells II. The first two steps of invasion of host cells by bacterial viruses. J. Exper. Med., 94, 177-189.

Ginsberg, H. S. and Horsfall, F. L., Jr. (1951): Characteristics of the multiplication cycle of pneumonia virus of mice (PVM). J. Exper. Med., 93, 151-160.

Gordon, L. E., Birkeland, T. M. and Dodd, M. C. (1952): Growth of Newcastle disease virus in the embryonated egg. Proc. Soc. Exper. Biol. \& Med., 80, 205-210.

Henle, W. (1949): Studies on host-virus interactions in the chick embryo-influenza virus system I. Adsorption and recovery of seed virus. J. Exper. Med., 90, 1-11.

Henle, W. (1953): Multiplication of influenza virus in the entodermal cells of the allantois of the chick embryo. in Advances in Virus Research I., Academic Press, New York, N. Y.

Horsfall, F. L., Jr. (1954): On the reproduction of influenza virus. Quantitative studies with procedures which enumerate infective and hemagglutinating virus particles. J. Exper. Med., 100, 135-161.

Hoyle, L. (1950) : The multiplication of influenza viruses in the fertile egg. J. Hyg., 48, 277-297.

Koprowska, I. and Koprowski, H. (1953): Morphologic and biologic changes in a mouse ascites tumor following induced infection with certain viruses. Cancer Res., 13, 651-660.

Lahelle, O. and Ward, T. G. (1951): Purification and concentration of mouse encephalomyelitis virus by hemagglutination. J. Immunol., 67, 75-81.

Lèpine, P., Wielgosz, G. and Reinè, L. (1951) : Courbe de croissance du virus vaccinal dans la membrane chorio-allantoidienne de l'oeuf. Ann. Inst. Pasteur, 81, 77-83.

Levine, S. and Sagik, B. P. (1956): The interactions of Newcastle disease virus (NDV) with chick embryo tissue culture cells: Attachment and growth. Virology, 2, 57-68.

Lowell, F. G. and Buckingham, M. (1948): A comparison of the effect of various salt concentrations on the agglutination of red cells by influenza A virus and antibody. J. Immunol., 58, 229-236.

Modi, N. L. and Tobin, J. O'H. (1954): Observations on the growth of herpes simplex virus in the chorio-allantois of the developing chick embryo and in tissue culture. Brit. J. Exper. Path., 35, 595-602.

Moore, A. E. and Diamond, L. C. (1953): Factors influencing the effect to hemagglutinating viruses on tumor cell suspensions. J. Immunol., 71, 441-445.

Morris, M. C. (1953): The relation between the infectivity and hemagglutinin of murine encephalomyelitis virus (GDVII). J. Immunol., 70, 39-49. 
Murphy, J. S. and Bang, F. B. (1952): Observations with the electron microscope of the chick chorio-allantoic membrane infected with influenza virus. J. Exper. Med., 95, 259-268.

Oya, A. (1955): On the mode of production of hemagglutinin and virus particles in the chorioallantoic membranes infected with variola and with vaccinia viruses. Jap. J. M. Sc. \& Biol., 8, 399-411.

Puck, T. T., Garen, A. and Coline, J. (1951): The mechanism of virus attachment to host cells I. The role of ions in primary reaction. J. Exper. Med., 93, 65-88.

Scherer, W. F. (1953): The utilization of a pure strain of mammalian cells (Earle) for the cultivation of viruses in vitro I. Multiplication of pseudorabies and herpes simplex viruses. Am J. Path., 29, 113-137.

Scherer, W. F., Syverton, J. T. and Gey, G. O. (1953): Studies on the propagation in vitro of poliomyelitis viruses IV. Viral multiplication in a stable strain of human malignant epithelial cells (strain HeLa) derived from an epidermoid carcinoma of the cervix. J. Exper. Med., 97, 695-709.

Schlesinger, M. (1932) : Ueber die Binding des Bacteriophages an homologe Bakterien. Zeitschr. Hyg., 141, 136-160.

Scott, T. F. McN. (1948) : in Diagnostic Procedure for Virus and Rickettsial Diseases, p. 250, Am. Public Health Assoc., New York.

Scott, T. F. McN., Coriell, L. L. and Blank, H. (1949) : in Diagnosis of Viral and Rickettsial Infections (editor Horsfall, F. L., Jr.), pp. 83-91, Columbia University Press, New York.

Scott, T. F. McN., Coriell, L. L., Blank, H. and Gray, A. (1953) : The growth curve of the virus of herpes simplex on the chorioallantoic membrane of the embryonated hen's egg. J. Immunol., 71, 134-144

Sigel, M. M., Girardi, A. J. and Allen, E. G. (1951) : Studies on psittacosis-lymphogranuloma group I. The patterns of multiplication of meningopneumonitis virus in the allantois of the chick embryo. J. Exper. Med., 94, 401-413.

Weiss, E. and Huang, J. S. (1954): The infected cell count method of titration of feline pneumonitis virus. J. Infect. Dis., 94, 107-125.

Wildy, P. (1954): The growth of herpes simplex virus. Australian J. Exper. Biol. \& M. Sc., 32, 605-620.

Wyckoff, M. W. G. (1953) : Formation of the particles of influenza virus. J. Immunol., 70, 187-196.

Yoshino, K. and Taniguchi, H. (1956): Quantitative studies on the interactions between herpes simplex virus and ectodermal cell of chorioallantoic membrane of fertile hen's egg by means of the cover slip infection system II. Growth curve with special reference to the demonstration of non-infectious phase by removal of surface virus. Jap. J. M. Sc. \& Biol., 9, 321-339.

Zinsser, H. and Tang, F. F. (1929): Further experiments on the agent of herpes. J. Immunol., 17, 343-355. 


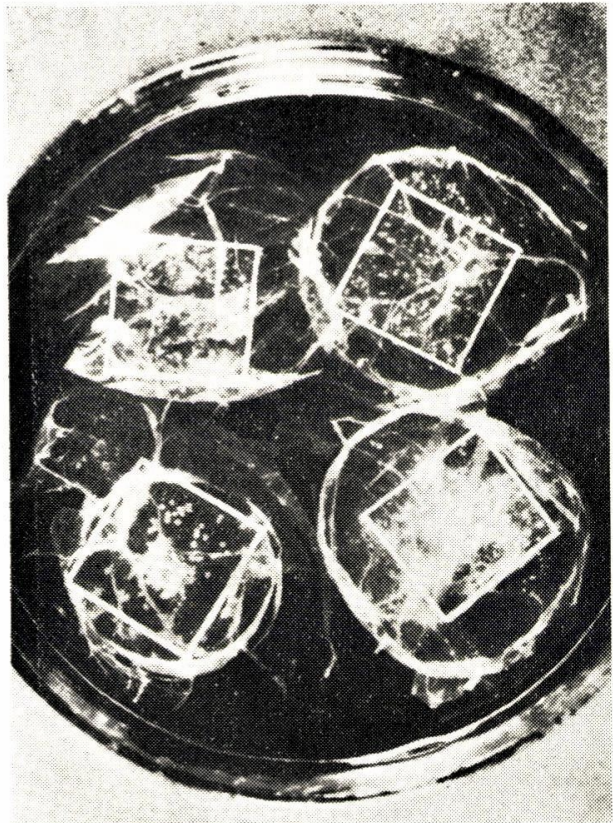

Fig. 2. CAM's randomly selected from the experiments of Table 5 . Square denotes the size and shape of the cover slip used for infection.

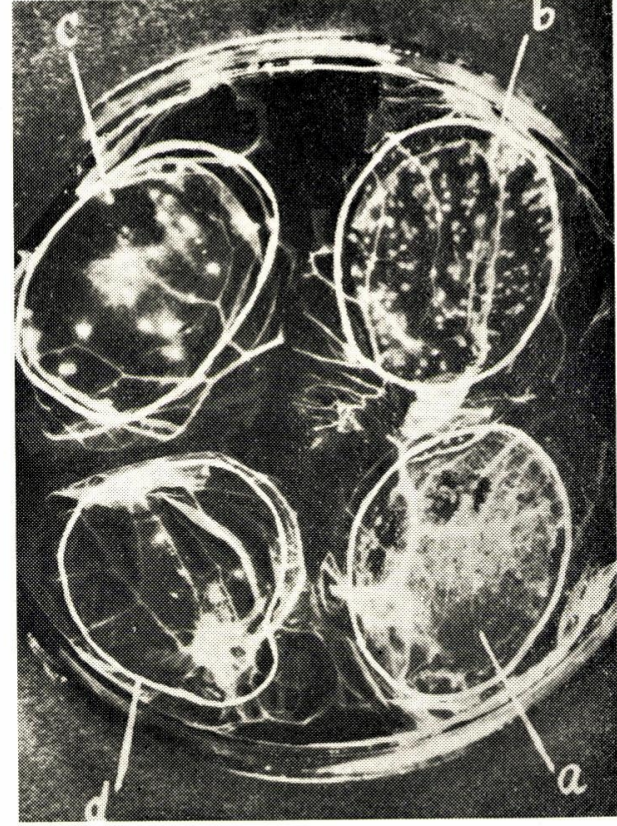

Fig. 3. A typical titration result. White line indicates the borderline of exposed part of the CAM.

a: (from $10^{-3}$ dilution) confluent lesion.

b: $\left(10^{-4}\right)$ c: $\left(10^{-5}\right)$ d: $\left(10^{-6}\right)$ scattered pocks. 